\title{
Increase in gonorrhoea among very young adolescents, Catalonia, Spain, January 2012 to June 2013
}

N Vives (nvives@iconcologia.net)1,2,3,4, R Lugo ${ }^{1,2,3}$, E López $^{1,2,3,4}$, P Garcia de Olalla ${ }^{2,5}$, S Minguell ${ }^{6}$, I Barrabeig7, P Pons ${ }^{6}$, E LopezGrado $^{8}$, I Ferré 9 , R Escriche ${ }^{10}$, P Armengol ${ }^{11}$, M Vall ${ }^{11}$, P Soler-Palacin ${ }^{2}$, I Leon ${ }^{13}$, I Gascon ${ }^{13}$, A M Vicente ${ }^{14}$, G Falguera ${ }^{8}$, A Avecilla-

Palau $^{9}$, C Martinez $^{10}$, M J Barberá ${ }^{11}$, V González ${ }^{1,2,3,15}$, J Caylà ${ }^{2,5}$, J Casabona ${ }^{1,2,3,4}$

1. Centre for Epidemiological Studies on STI/HIV/AIDS in Catalonia (CEEISCAT)-ICO-Agència de Salut Pública de Catalunya, Barcelona, Spain

2. CIBER Epidemiología y Salud Pública (CIBERESP), Madrid, Spain

3. Institut d'Investigació Germans Trias i Pujol (IGTP), Badalona, Spain

4. Department of Paediatrics, Obstetrics, Gynaecology and Preventive Medicine, Universitat Autònoma de Barcelona (UAB), Barcelona, Spain

5. Epidemiological service of Public Health Agency of Barcelona, Barcelona, Spain

6. Epidemiological Surveillance Unit of Tarragona, Tarragona, Spain

7. Epidemiological Surveillance Unit of Costa de Ponent, Hospitalet del Llobregat, Spain

8. Reproductive and Sexual Health Care Programme, Centre d’Atenció Primària (CAP) Sant Fèlix, Institut Català de la Salut (ICS) , Sabadell, Spain

9. Reproductive and Sexual Health Care Centre, Badalona Serveis Assistencials (BSA), Badalona, Spain

10. Reproductive and Sexual Health Care Programme, CAP Manso, ICS, Barcelona, Spain

11. Sexually Transmitted Infections Unit, Hospital Universitari Vall d'Hebrón, ICS, Barcelona, Spain

12. Unitat de Patologia Infecciosa i Immunodeficiències de Pediatria. Hospital Universitari Vall d'Hebron, Institut de Recerca Vall d’Hebron, Universitat Autònoma de Barcelona, Barcelona, Spain

13. CAP La Marina, ICS, Barcelona, Spain

14. CAP Roquetes-Canteres, ICS, Barcelona, Spain

15. Microbiology Service, Hospital Universitari Germans Trias i Pujol, ICS, Badalona, Spain

\section{Citation style for this article:}

Vives N, Lugo R, López E, Garcia de Olalla P, Minguell S, Barrabeig I, Pons P, Lopez-Grado E, Ferré I, Escriche R, Armengol P, Vall M, Soler P, Leon I, Gascon I, Vicente AM, Falguera G, Avecilla-Palau A, Martinez C, Barberá MJ, González V, Caylà J, Casabona J. Increase in gonorrhoea among very young adolescents, Catalonia, Spain, January 2012 to June 2013. Euro Surveill. 2013;18(33):pii=20560. Available online: http://www.eurosurveillance.org/ViewArticle.aspx?Articleld=20560

Between January 2012 and June 2013, 27 sexually transmitted infections were reported in adolescents aged 13-15 years in Catalonia, Spain. In the first half of 2013, there were nine cases of gonorrhoea, while in the same period of 2012, there was one. In June 2013, two gonorrhoea cases aged 13-14 years, linked to a common source through a social network, were reported. The public health response should be adapted to this vulnerable population.

On 21 June 2013, the Public Health Agency of Catalonia received an alert from the Public Health Agency of Barcelona about the occurrence of gonorrhoea in two boys aged 13 and 14 years. The boys were coinfected with Chlamydia and probably linked to a common exposure source, through an online social network. After case investigation, these two cases were linked to a third adolescent, a girl aged 14 years. As of 30 June, the Centre for Epidemiological Studies on STI/HIV/AIDS of Catalonia - responsible for the surveillance of sexually transmitted infections (STIs), including HIV/AIDS, for the Public Health Agency of Catalonia - observed a steady increase over the previous six months in the number of gonorrhoea cases reported among very young adolescents (13-15 years), which had not been identified as clusters.

We report here on the emergence of STIs among very young adolescents in Catalonia and draw attention to the potential risk of a gonorrhoea outbreak and transmission of other STIs. We present a preliminary descriptive analysis of epidemiological and microbiological characteristics of cases from 1 January 2012 to 30 June 2013. We also compare the number of cases reported during first six months of 2012 and of 2013.

\section{Surveillance of sexually transmitted infections in Catalonia}

Three institutional information systems are used for STI surveillance in Catalonia: a name-based mandatory disease notification registry (MDI), STI sentinel surveillance registry (RITS) and microbiological notification system (SNMC), as described elsewhere [1]. Infectious syphilis, gonorrhoea and lymphogranuloma venereum (LGV) have been included in the MDI since 2007 [2]. Other STIs, such as genital Chlamydia infection, trichomoniasis, genital herpes and genital warts due to human papilloma virus infection, are monitored through the RITS and SNMC.

STI case-report data from the three surveillance systems are entered into the Public Health Agency of Catalonia's Epidemiological Repository System, allowing complementarity of variables and capture of cases. Confidentiality and data protection are assured [3].

STI case definitions used for surveillance reporting are standardised, as the European Union definitions 
TABLE 1

Epidemiological and behavioural characteristics of adolescents aged 13-15 years with sexually transmitted infections, Catalonia, Spain, January 2012-June 2013 $(\mathrm{n}=27)$

\begin{tabular}{|c|c|c|c|}
\hline \multirow[b]{2}{*}{ Characteristic } & \multicolumn{3}{|c|}{ Number of cases } \\
\hline & Gonorrhoea & $\begin{array}{l}\text { Other } \\
\text { STIs }\end{array}$ & Total \\
\hline Demographic & $\mathrm{n}=10$ & $\mathrm{n}=17$ & $n=27$ \\
\hline \multicolumn{4}{|l|}{ Sex } \\
\hline Male & 7 & 1 & 8 \\
\hline Female & 3 & 16 & 19 \\
\hline \multicolumn{4}{|l|}{ Age (years) } \\
\hline 13 & 1 & o & 1 \\
\hline 14 & 1 & 5 & 6 \\
\hline 15 & 8 & 12 & 20 \\
\hline \multicolumn{4}{|l|}{ Country of birth ${ }^{a}$} \\
\hline Spain & 2 & 11 & 13 \\
\hline Outside Spain & 7 & 4 & 11 \\
\hline \multicolumn{4}{|l|}{ Health provider reporting the case } \\
\hline Paediatric service & 4 & 0 & 4 \\
\hline $\begin{array}{l}\text { Sexually Transmitted Infection } \\
\text { Unit }\end{array}$ & 0 & 2 & 2 \\
\hline $\begin{array}{l}\text { Sexual and reproductive health } \\
\text { service }\end{array}$ & 1 & 6 & 7 \\
\hline $\begin{array}{l}\text { Family/general practitioner } \\
\text { team }\end{array}$ & 1 & 6 & 7 \\
\hline Hospital emergency department & 4 & 3 & 7 \\
\hline History of STIs and behaviour & $\mathrm{n}=7$ & $n=8$ & $\mathrm{n}=15$ \\
\hline \multicolumn{4}{|l|}{ Sexual orientation } \\
\hline Heterosexual & 4 & 7 & 11 \\
\hline Homosexual & o & 1 & 1 \\
\hline Unknown & 3 & 0 & 3 \\
\hline \multicolumn{4}{|l|}{ Previous STI in the last 12 months } \\
\hline Yes & 0 & 1 & 1 \\
\hline No/unknown & 7 & 7 & 14 \\
\hline \multicolumn{4}{|l|}{ HIV positive } \\
\hline Yes & 0 & 0 & 0 \\
\hline No & 1 & 3 & 4 \\
\hline Unknown status & 6 & 5 & 11 \\
\hline \multicolumn{4}{|l|}{ Condom use at last sex } \\
\hline Yes & o & 3 & 3 \\
\hline No/Unknown & 7 & 5 & 12 \\
\hline \multicolumn{4}{|c|}{ New sex partner in the last three months } \\
\hline Yes & 0 & 2 & 2 \\
\hline No/Unknown & 7 & 6 & 13 \\
\hline \multicolumn{4}{|c|}{ Number of sex partners in the last 12 months } \\
\hline$\leq 2$ & 0 & 7 & 7 \\
\hline$>2$ & 0 & 1 & 1 \\
\hline Unknown & 7 & 0 & 7 \\
\hline \multicolumn{4}{|l|}{ Contact tracing initiated } \\
\hline Yes & 2 & 5 & 7 \\
\hline No/unknown & 5 & 3 & 8 \\
\hline
\end{tabular}

HIV: human immunodeficiency virus; STI: sexually transmitted infection.

${ }^{\mathrm{a}}$ Information on country of birth was not available for all cases. are used [4]. Very young adolescence was defined as a recorded age at STI diagnosis of between 13 and 15 years. A case reported from more than one of the three surveillance systems was counted only once in the analysis. When duplicates were detected, cases in the microbiological notification system were excluded from the analysis.

\section{Sexually transmitted infections among}

adolescents aged $13-15$ years

Epidemiological and behavioural characteristics of STIs among adolescents aged $13-15$ years in Catalonia are shown in Table 1 and the reported STIs in Table 2.

A total of 27 STI cases were reported during the study period (January 2012 to June 2013). Of these, 13 were reported during the first six months of 2013; in the first half of 2012, nine cases were reported (Table 2). This increase was due mainly to the increased number of cases of gonorrhoea. The number of cases with other STIs was very low, making comparisons between the years difficult. Overall, during 2007 to 2012, three syphilis cases (one in 2007, 2011 and 2012) and one gonorrhoea case in 2011 were reported among very young adolescents aged 13-15 years.

\section{Gonorrhoea}

A total of 10 very young adolescents (13-15 years) with gonorrhoea were reported to the Public Health Agency of Catalonia during January 2012 to June 2013. Seven were boys and seven were born outside of Spain, in Latin America and the Caribbean. Sexual orientation (heterosexual) was known for only four of the cases. Paediatricians notified four of the 10 cases.

Gonorrhoea was the second most frequently reported STI during the study period: nine cases were reported in the first half of 2013 whereas in the same period of 2012, there was only one (Table 2).

Other sexually transmitted infections

From January 2012 to June 2013, a total of 17 cases of other STIs were reported among adolescents aged 14-15 years. All except one were girls; one 15 year-old homosexual boy with syphilis was reported. Unlike the situation for the gonorrhoea cases, only four of the 17 cases with other STIs were born outside of Spain.

Chlamydia trachomatis infection was the most common STI (11 of the 27 cases) and Gardnerella vaginalis infection ranked third $(3 / 27)$. When comparing January to June of 2012 versus 2013, no increase was observed (Table 2).

History of sexually transmitted infections

Most of the cases did not know their HIV status, one had a previous STI in the past year and only three reported condom use at last sex. One case aged 14 years reported having three sexual partners during the last 12 months and two cases reported having a new sexual partner during last three months. 
TABLE 2

Sexually transmitted infections reported among adolescents aged 13-15 years, Catalonia, Spain, January 2012-June 2013

\begin{tabular}{|l|c|c|c|}
\hline \multirow{2}{*}{ Infection } & \multicolumn{3}{|c|}{ Number of cases } \\
\cline { 2 - 4 } & January 2012-June 2013 & January-June 2012 & January-June 2013 \\
\hline Infectious syphilis & $\mathbf{1}$ & $\mathbf{1}$ & 0 \\
\hline Gonorrhoea & 10 & 1 & 9 \\
\hline Lymphogranuloma venereum & 0 & 0 & 0 \\
\hline Chlamydia trachomatis & 11 & 0 & 0 \\
\hline Herpes simplex virus & $\mathbf{1}$ & 0 & 0 \\
\hline Trichomonas vaginalis & 0 & 1 & 0 \\
\hline Genital warts due to human papilloma virus infection & 1 & $\mathbf{2}$ & 0 \\
\hline Gardnerella vaginalis & 3 & $\mathbf{9}$ & $\mathbf{1 3}$ \\
\hline Total & $\mathbf{2 7}$ & & 0 \\
\hline
\end{tabular}

Most of these very young adolescents (7/27) were diagnosed in a sexual and reproductive health service or by a family/general practitioner team $(n=7)$. Four cases were diagnosed by paediatricians and two were diagnosed at the Sexually Transmitted Infection Unit. Contact tracing investigations, initiated by the healthcare provider who diagnosed the patient, were carried out for seven of the 15 cases for whom epidemiological information was available (initiation of contract tracing following diagnosis is obligatory in Catalonia). No information on use of a newly introduced partner notification card was reported. Active contact tracing follow-up was carried out by the Barcelona city epidemiological surveillance unit for the cluster of three gonorrhoea cases.

\section{Microbiological detection}

The microbiological notification system detected $C$. trachomatis $(n=8)$, Neisseria gonorrhoeae $(n=3)$ and herpes simplex virus $(n=1)$. Polymerase chain reaction (PCR) was used to detection of $C$. trachomatis and no further molecular serovar typing was performed. The three $N$. gonorrhoeae detections were confirmed by culture, all of which were sensitive to ceftriaxone. No molecular typing was carried out.

\section{Background}

Sexual activity in early adolescence contributes to an increased burden of unplanned pregnancy, abortion, transmission of STIs, including exposure to HIV and can have an impact on a young person's general health $[5,6]$.

Spain has the lowest legal age of consent for sexual activity (13 years) in the European Union [7]. According to the last National Sexual Health and Reproduction Survey, $34 \%$ of those interviewed declared starting sexual intercourse before 16 years of age - two-fold higher than in the previous survey $(12 \%$ in 2003$)[8,9]$. In contrast, the legal age for use of health services without parental consent is 16 years [10].
In Catalonia, epidemiological data from individualised mandatory STI reporting, introduced in 2007 [2], showed an increase between years 2007 and 2012 for gonorrhoea and syphilis and two outbreaks of lymphogranuloma venereum (LGV). Resistance of $N$. gonorrhoeae to ceftriaxone was documented in Catalonia in 2011 [1].

Approximately $40 \%$ of persons with STIs in all age groups in Catalonia are born outside Spain [1]. Sex between men who have sex with men is the route of exposure in about 30\% of gonorrhoea cases, $60 \%$ of syphilis cases and $100 \%$ of LGV cases. Data by age group have only been available since 2007. Young people aged $15-24$ years represent about $24 \%$ of all reported gonorrhoea cases and $11 \%$ of syphilis cases, with no change over time (2007-2012).

\section{Discussion}

The increase seen in the number of gonorrhoea cases and the occurrence of other STIs in these very young adolescents raises issues regarding the health and vulnerability of this population [11]. In addition, the data indicate a special vulnerability of foreign-born minors diagnosed with gonorrhoea, as the proportion of those born outside Spain is higher than that seen for other STIs and in other age groups [1]. Rapid public health responses are needed to address these issues in very young adolescents (Box).

The reporting of two gonorrhoea cases linked to a common third adolescent and exposure through a social network points towards a potential risk for gonorrhoea to spread among a young population with access to new technologies. In addition, the occurrence of noncongenital syphilis in a homosexual boy (born outside Spain) highlights the potential transmission of this infection and potential for increased exposure to HIV due to unprotected sexual intercourse. In Catalonia, syphilis is mostly observed among men who have sex with men, with $37 \%$ HIV coinfection [1]. 


\section{Box}

Public health response required to prevent sexually transmitted infections in very young adolescents (aged $13-15$ years)

- Communicate to public health agencies and scientific societies the increased vulnerability of this population for STI/HIV transmission.

- Alert paediatricians, family/general practitioners and contraception and sexuality youth centres about the potential transmission of gonorrhoea and other STIs in minors aged under 16 years.

- Review STI surveillance procedures and STI clinical management guidelines regarding minors aged under 16 years.

- Reinforce youth-sensitive counselling, screening and partner notification among very young adolescents.

- Reinforce sexual health education at an early age, as well as training of primary care health professionals and counsellors about sexual health issues in very young adolescents.

- Bring to the attention of the multisector entities (governmental commissions, public health-epidemiologica commissions, maternal-child health comissions and nongovernmental and community-based organisations) about these emerging health issues.

HIV: human immunodeficiency virus; STI: sexually transmitted infection.

Sex-related behaviour within the very young adolescents showed a low condom use at last sexual intercourse; one case had had more than two sexual partners in the last 12 months. During early puberty, most minors enter into a rapid increase in cognitive and emotional development and face a period influenced by peers and other adults [5,6]. Further analysis of sexual behaviour and STI/HIV exposure should be carried out in this population.

Health professionals, in particular paediatricians, should be aware of the recent cases and be prepared to test for these infections in their very young adolescent patients. There should also be adequate follow-up, which respects privacy and confidentiality issues and the cognitive maturity of these very young adolescents concerning their own sexual health.

The three surveillance systems have been shown to be useful, allowing us to identify and describe the epidemiology of this vulnerable population. Nevertheless, the coverage and case-finding capacity of these systems needs to be improved.

The data presented show that important STIs such as syphilis, chlamydia and gonorrhoea are appearing in very young adolescents. These findings are consistent with data from European countries, where an increase in the proportion of STI in the age group 15-19 years is being observed [12]. This observation raises important public health issues regarding age at first sexual intercourse, unprotected sex and other high-risk behaviours, including the use of social networks for sex and contact with high-risk populations in urban areas. Further analysis should be carried out to identify risk determinants, in order to design specific public health programmes and interventions that potentiate a comprehensive approach to young people's sexual health.

\section{Acknowledgements}

We are grateful to all colleagues from the local epidemiology surveillance units (UVE), STI sentinel surveillance network (RITS) and local laboratories (SNMC) for the provided data to the Integrated STI/HIV/AIDS Surveillance System. We also acknowledge the work of our colleagues from the CEEISCAT, specifically Noemi Romero and Rafael Muñoz for their timely and quality of the data entered. Finally, the authors would like to thank: The Catalan Public Health Agency, Catalan Government (Agència de Salut Pública de Catalunya, Generalitat de Catalunya), and the CIBER Epidemiología y Salud Pública (CIBERESP), Spain.

Conflict of interest

None declared.

\section{Authors' contributions}

Designed the study: NV, RL and EL; Wrote the first draft: NV; Collected, synthesised and analysed the data: NV, RL, EL, PGO, SM, IB, PP, ELG, IF, RE, PA, MV, PSP, IL, IG, AMV, GF, $A A P, C M, M J B, V G, J A C, J C$; Interpreted the results critically and revised the article to ensure important intellectual content: NV, RL, EL and JC; All authors read and approved the final manuscript.

\section{*Authors' correction:}

The name of P Soler-Palacin was corrected in the list of authors on 30 September 2013. 


\section{References}

1. Centre d'Estudis Epidemiològics sobre les Infeccions de Transmissió Sexual i Sida de Catalunya (CEEISCAT). Sistema Integrat de vigilància epidemiològica de la SIDA/VIH/ ITS a Catalunya (SIVES). [Integrated surveillance of HIV / AIDS / STI Catalonia (SIVES)]. Barcelona: Generalitat de Catalunya, Agència de Salut Pública de Catalunya; 2013. Spanish. Available from: http://www.ceeiscat.cat/documents/ SIVES_2012.pdf

2. DECRET 391/2006, de 17 d'octubre, pel qual es modifica el circuit de notificació de les malalties de declaració obligatòria i brots epidèmics al Departament de Salut. Barcelona:

Document Oficial Generalitat de Catalunya (DOGC) no. 4743, (19 Oct2006).Catalonia. [Decree 391/2006 of 17 October, by which modifies the reporting notifiable disease circuit and outbreaks at the Department of Health. Official Journal. no. 4743 (Oct 19.10.2006)]. Spanish.

3. LEY ORGÁNICA 15/1999, de 13 de diciembre, de Protección de Datos de Carácter Personal.[Law 15/1999 of 13 December, of Protection of Personal Data]. Madrid: Boletín Oficial del Estado (BOE) no. 298 (14 Dec 1999). Spanish.

4. European Commission. Commission Implementing Decision of 8 August 2012 amending Decision 2002/253/EC laying down case definitions for reporting communicable diseases to the Community network under Decision No 2119/98/EC of the European Parliament and of the Council. Official Journal of the European Union. Luxembourg: Publications Office of the European Union. 27.9.2012: L 262. Available from: http://eurlex.europa.eu/LexUriServ/LexUriServ.do?uri=0J:L:2012:262:00 01:0057:EN:PDF

5. World Health Organization (WHO). The sexual and reproductive health of younger adolescents. Research issues in developing countries. Background paper for a consultation. Geneva: WHO; 2011. Available from: http://libdoc.who.int/ publications/2011/9789241501552_eng.pdf

6. Cook RJ, Erdman JN, Dickens BM. Respecting adolescents' confidentiality and reproductive and sexual choices. Int I Gynaecol Obstet. 2007;98(2):182-7. http://dx.doi.org/10.1016/j.ijg0.2007.04.018 PMid: 17582416

7. LEYORGÁNICA $2 / 1998$, de 15 de junio, por la que se modifican el Código Penal y la Ley de Enjuiciamiento Criminal. [LEYORGÁNICA 2/1998 of 15 June, imposing a modification of the Criminal Code and the Criminal Law of judgment]. Madrid: Boletín Oficial del Estado (BOE). No. 143; 16 June 1998. Spanish.

8. Resumen ejecutivo de la Encuesta Nacional de Salud Sexual (2009). [Executive Summary of the National Sexual Health Survey (2009)]. Madrid: Ministerio de Sanidad, Servicios Sociales e Igualdad; 2009. [Accessed 25 Jul 2013]. Spanish. Available from: http://www. msssi.gob.es/organizacion/sns/planCalidadSNS pdf/equidad/EncuestaNacionaSaludSexual2009/ resumenEjecutivoEncuestaSaludSexual_2009.pdf

9. Instituto Nacional de estadística (INE); Ministerio de sanidad y consumo, Secretaría del Plan Nacional sobre el Sida. Encuesta de Salud y Hábitos Sexuales 2003. Informe general. [Survey of health and sexual habits 2003. General report]. Madrid: INE; 2003. [Accessed 25 Jul 2013]. Spanish. Available from: http:// www.ine.es/ss/Satellite? param $1=$ PYSDetalleGratuitas $\&$ c $=$ INEP ublicacion_C\&p=1254735110672\&pagename $=$ ProductosYServic ios $\% 2$ FPYSLayout \&cid $=1259931856701 \& \mathrm{~L}=0$

10. LEY 41/2002, de 14 de noviembre, básica reguladora de la autonomía del paciente y derechos y obligaciones en materia de información y documentación clínica. [Law 41/2002, November 14 , regulating patient autonomy and rights and obligations of information and clinical documentation. Madrid: Boletín Oficial del Estado (BOE). No. 274; 15 Nov 2002. Spanish.

11. World Health Organization (WHO). The WHO Strategic Approach to strengthening sexual and reproductive health policies and programmes. Geneva: WHO; 2007. Available from: http://whqlibdoc.who.int/hq/2007/WHO_RHR_07.7_eng.pdf

12. European Centre for Disease Prevention and Control (ECDC). Sexually transmitted infections in Europe 1990-2010. Stockholm: ECDC; 2012. 